\section{Physicochemical Properties of a Bioceramic Repair Material - BioMTA}

Hernán Coaguila-Llerena1 ${ }^{1}$, Victor Manuel Ochoa-Rodriguez ${ }^{1}{ }^{\circledR}$, Gabriela Mariana Castro-Núñez ${ }^{1}$, Gisele Faria ${ }^{1}{ }^{\mathbb{D}}$, Juliane Maria GuerreiroTanomaru' ${ }^{10}$, Mario Tanomaru-Filho ${ }^{1}$ (i)
'Department of Restorative Dentistry, School of Dentistry, UNESP - Universidade Estadual Paulista, Araraquara, SP, Brazil

Correspondence: Mario TanomaruFilho, Rua Humaitá, 1680, 14.801-903 Araraquara, SP, Brasil. Tel: + 55-16-3301-6390. e-mail: tanomaru@uol.com.br

\begin{abstract}
This study aimed to assess the physicochemical properties of a repair material in the Brazilian market, BioMTA, in comparison to other two materials currently in use (Biodentine and MTA Angelus). The initial setting time was evaluated using Gillmore needle. The $\mathrm{pH}$ was measured with a pH-meter after $24 \mathrm{~h}, 3,7,14$ and 21 days. The radiopacity was determined using the equivalence in millimeters of aluminum ( $\mathrm{mm} \mathrm{Al}$ ) from digitized occlusal radiographs. Solubility was determined after immersion in water for 7 days. The data were analyzed by one-way ANOVA and Tukey tests $(\alpha=0.05)$. The BioMTA initial setting time (5.2 min) was lower than the other materials $(p<0.05)$. All materials showed an alkaline $\mathrm{pH}$ at 21 days. At $24 \mathrm{~h}$, BioMTA was the most alkaline material $(\mathrm{p}<0.05)$; and at $3,7,14$ and 21 days there was no difference between BioMTA and Biodentine ( $p>0.05)$, both being more alkaline than MTA Angelus $(p<0.05)$. The radiopacity of BioMTA ( 4.2 $\mathrm{mm}$ Al) was significantly higher compared to Biodentine $(\mathrm{p}<0.05)$ and lower than MTA Angelus $(p<0.05)$. The solubility of the materials was $-4.2 \%,-1.6 \%$ and $4.1 \%$ for BioMTA, MTA Angelus and Biodentine, respectively, with a significant difference between them $(p<0.05)$. Therefore, it can be concluded that BioMTA displayed a shorter setting time, an alkaline $\mathrm{pH}$, a higher radiopacity, and a gain in mass.
\end{abstract}

Key Words: biocompatible materials, physical and chemical properties, root canal treatment.

\section{Introduction}

An ideal repair material should seal any possible communication between the root canal system and adjacent tissues (1). The mineral trioxide aggregate (MTA) is widely used for several applications in the endodontic practice due to its suitable properties (2). Likewise, it has excellent biological response and biocompatibility (3). However, it has disadvantages that generate serious concerns such as tooth discoloration (4), delicate handling and long setting time (1). Particularly, tooth discoloration has been attributed to the radiopacifying agent in MTA composition, the bismuth oxide (5). Over the years, several types of cements have been developed with similar characteristics to those of MTA but without their disadvantages.

Biodentine (Septodont, Saint-Maur-des-Fossés, France) is a tricalcium silicate cement, which is considered as a substitute for dentin and an alternative to MTA (6). Its radiopacifying agent is zirconium oxide $(6,7)$. The applications in Endodontics include the same as MTA, such as pulp capping, pulpotomy, apexification, perforation / external resorption repair, and as root-end filling (7).

BioMTA (Intradent, Belém, PA, Brazil) is a bioceramic repair material recently introduced and distributed in the Brazilian market that shows similar composition to RetroMTA (BioMTA, Seoul, Korea). It consists of calcium carbonate, silicon dioxide, aluminum oxide and calcium zirconium complex as radiopacifying agent (8). Althought BioMTA is currently available in the Brazilian market the physicochemical properties of this material version have not been assessed. Therefore, this study aimed to assess the physicochemical properties of BioMTA, Biodentine and MTA Angelus (Angelus, Londrina, PR, Brazil) repair cements, based on the standards of the International Organization for Standardization (ISO) 6876 (9) and Specification No. 57 of the American National Standard Institute/American Dental Association - ANSI/ADA (10). The null hypothesis is that there would be no difference in the physicochemical properties of BioMTA, Biodentine and MTA Angelus.

\section{Material and Methods}

The physicochemical properties of BioMTA (Intradent), Biodentine (Septodont) and MTA Angelus (Angelus, Londrina, PR, Brazil) were evaluated by assessing their setting time, $\mathrm{pH}$, radiopacity and solubility. The composition and powder/liquid ratio of each material are described in Table 1.

The cements were handled on a glass plate following the manufacturers' recommendations until a homogeneous mixture was obtained. The BioMTA was mixed using a plastic spatula (Fuji Spatula, GC Corporation, Tokyo, Japan) for 
20 s. Biodentine was prepared by shaking the capsule in amalgamator (Ultramat 2, SDI Limited Bayswater, Victoria 3153, Australia) for $30 \mathrm{~s}$. The MTA Angelus was manipulated with a spatula No. 24 (Golgran, Sao Caetano do Sul, SP, Brazil) for $30 \mathrm{~s}$.

\section{Setting Time}

Samples of each cement were prepared as discs ( $n=6$ per material), which were made by inserting each cement into ring-shaped gypsum molds with the dimensions 10 $\mathrm{mm}$ in diameter and $1 \mathrm{~mm}$ in thickness. The indentation technique by using Gillmore needle, which has $2 \pm 0.1 \mathrm{~mm}$ diameter and $100 \pm 0.5 \mathrm{~g}$ weight according to ISO 6876 (9), was used to determine the initial setting time. During the tests, the samples were kept in an oven at $37^{\circ} \mathrm{C}$ and $95 \%$ humidity. The average setting time was recorded from the manipulation of each cement until the Gillmore needle did not cause more indentations on the surface of the samples.

\section{pH Analysis}

For this test, each cement $(n=10)$ was inserted into polyethylene tubes with $10 \mathrm{~mm}$ long and $1 \mathrm{~mm}$ diameter dimensions. Each tube was immersed into flasks containing $10 \mathrm{~mL}$ of deionized water and kept at $37^{\circ} \mathrm{C}$ in an oven for $24 \mathrm{~h}, 3,7,14$ and 21 days. At each time interval, the tubes were removed from the flasks and placed into new flasks with $10 \mathrm{~mL}$ of deionized water. At each time interval, the $\mathrm{pH}$ of the solution contained in each tube was measured by using a previously calibrated digital pH-meter (DM-22, Digimed, São Paulo, SP, Brazil) at $25^{\circ} \mathrm{C}$ room temperature. As a control group, the $\mathrm{pH}$ of deionized water without immersed cement was measured.

\section{Radiopacity}

This test was performed according to ISO 6876 (9). Five samples of $10 \mathrm{~mm}$ diameter and $1 \mathrm{~mm}$ thickness of each cement were made by using Teflon molds. The samples were stored in an oven at $37{ }^{\circ} \mathrm{C}$ and $95 \%$ humidity for $24 \mathrm{~h}$ and placed on occlusal radiographic E-speed films
(Insight - Kodak Co., Rochester, NY, USA). Then, the samples were radiographed next to an 8-step aluminum wedge with $2 \mathrm{~mm}$ incremental steps. The focal length was set at $320 \mathrm{~mm}$ from the origin and zero degrees of vertical and horizontal X-ray beam angle. A GE-1000X-ray unit (General Electric, Milwaukee, WI, USA) was used at $65 \mathrm{kVp}$ and 7 $\mathrm{mA}$ during an exposure time of $0.25 \mathrm{~s}$. The radiographic films were digitized (11) using a digital photographic camera (Canon EOS T1, Tokyo, Japan) with a macro lens of $100 \mathrm{~mm}$ with the following parameters: lens-to-object distance of $58 \mathrm{~cm}$, ISO 200, aperture of 6.3 for the shutter and speed of $1 / 40 \mathrm{~s}$.

The images were evaluated by using the histogram tool of the Photoshop CC 2015 software for Windows (Adobe Systems Incorporated, Mountain View, CA, USA). The equivalence of radiopacity was determined in millimeters of aluminum ( $\mathrm{mm} \mathrm{Al}$ ) by using the method by Húngaro Duarte et al. (11).

\section{Solubility}

It was performed following the modified methodology of Carvalho-Junior et al. (12) based on ANSI/ADA No. 57 (10). The three cements were manipulated and placed in silicone molds $(n=6)$, with a $7.75 \mathrm{~mm}$ diameter and 1.5 $\mathrm{mm}$ thickness. A 5-cm nylon thread was placed in the center of the samples when the material was placed into the mold to provide stability during the experiment. The samples were kept in an oven at $37{ }^{\circ} \mathrm{C}$ and $95 \%$ humidity for three times their initial setting time. Then, the samples were removed from the molds, weighed on an HM-200 precision balance (A \& D Engineering, Inc., Bradford, MA, USA) and suspended by nylon threads attached to the plastic flasks, which contained $7.5 \mathrm{~mL}$ of deionized water. The plastic flasks were maintained at $37^{\circ} \mathrm{C}$ for 7 days. Next, the samples were removed, rinsed and placed in a silica dehumidifier chamber. These samples were measured every $24 \mathrm{~h}$ until the mass stabilization. The loss or increase in mass was calculated from the percentage of the original mass.

Table 1. Materials, composition, and powder/liquid ratio

\begin{tabular}{|c|c|c|}
\hline Material & Composition & Powder/liquid ratio \\
\hline $\begin{array}{l}\text { BioMTA (Intradent, } \\
\text { Belém, PA, Brazil) }\end{array}$ & $\begin{array}{l}\text { Powder: Calcium carbonate, silicon dioxide, aluminum oxide, calcium } \\
\text { zirconia complex (radiopacifier). Liquid: Distilled water }\end{array}$ & $\begin{array}{l}0.3 \mathrm{~g} \text { powder / } 3 \text { drops distilled } \\
\text { water from its dropper. }\end{array}$ \\
\hline $\begin{array}{l}\text { Biodentine (Septodont, } \\
\text { Saint-Maur-des- } \\
\text { Fossés, France) }\end{array}$ & $\begin{array}{l}\text { Powder: tricalcium silicate, calcium carbonate, zirconium oxide } \\
\text { (radiopacifier), dicalcium silicate, calcium oxide, iron oxide. Liquid: } \\
\text { aqueous solution of a hydrosoluble polymer with calcium chloride. }\end{array}$ & $\begin{array}{l}\text { Capsule with } 0.7 \text { g powder } \\
\text { / } 6 \text { drops of liquid. }\end{array}$ \\
\hline $\begin{array}{l}\text { MTA Angelus } \\
\text { (Angelus, Londrina, } \\
\text { PR, Brazil) }\end{array}$ & $\begin{array}{l}\text { Powder: silicon dioxide, potassium oxide, aluminum oxide, sodium oxide, } \\
\text { ferric oxide, sulfure trioxide, calcium oxide, bismuth oxide (radiopacifier), } \\
\text { magnesium oxide. Insoluble residues of calcium oxide, potassium } \\
\text { sulfate, sodium sulfate and crystalline silica. Liquid: distilled water. }\end{array}$ & $\begin{array}{l}1 \mathrm{~g} \text { powder / } 0.33 \mathrm{~mL} \\
\text { distilled water. }\end{array}$ \\
\hline
\end{tabular}




\section{Statistical Analysis}

All quantitative data were subjected to Shapiro-Wilk test $(\alpha=0.05)$ and presented normal distribution. Thus, the data were analyzed by one-way ANOVA and Tukey tests at $5 \%$ level of significance.

\section{Results}

\section{Setting Time}

The setting time values are shown in Table 2. BioMTA showed the shortest initial setting time ( $5.2 \mathrm{~min})(p<0.05)$, followed by MTA Angelus (15.6 min) showing significant differences between them $(p<0.05)$. Biodentine showed the longest initial setting time $(27.5 \mathrm{~min})(\mathrm{p}<0.05)$.

pH

At the end of the test (21 days), the three cements showed alkaline $\mathrm{pH}$ in comparison to the control group $(\mathrm{p}<0.05)$ as seen in Table 3. At $24 \mathrm{~h}$, BioMTA was the most alkaline (10.8) $(p<0.05)$. At $3,7,14$ and 21 days there was no difference between BioMTA and Biodentine ( $p>0.05)$. Both BioMTA and Biodentine were more alkaline than MTA Angelus $(p<0.05)$.

\section{Radiopacity}

The radiopacity data are shown in Table 2. MTA Angelus showed the highest radiopacity $(4.8 \mathrm{~mm} \mathrm{Al})(p<0.05)$, followed by BioMTA ( $4.2 \mathrm{~mm}$ Al) showing significant differences between them $(p<0.05)$. Biodentine showed the lowest radiopacity $(2.2 \mathrm{~mm} \mathrm{Al})(\mathrm{p}<0.05)$.

\section{Solubility}

As seen in Table 2, Biodentine was the only cement

Table 2. Initial setting time, radiopacity and solubility

\begin{tabular}{lccc}
\hline Material & $\begin{array}{c}\text { Initial setting } \\
\text { time }(\mathrm{min})\end{array}$ & $\begin{array}{c}\text { Radiopacity } \\
(\mathrm{mm} \mathrm{Al})\end{array}$ & Solubility (\%) \\
\hline BioMTA & $5.2( \pm 0,4)^{\mathrm{a}}$ & $4.2( \pm 0.2)^{\mathrm{a}}$ & $-4.2( \pm 0.7)^{\mathrm{a}}$ \\
Biodentine & $27.5( \pm 0.5)^{\mathrm{b}}$ & $2.2( \pm 0.2)^{\mathrm{b}}$ & $4.1( \pm 0.4)^{\mathrm{b}}$ \\
MTA Angelus & $15.6( \pm 1.2)^{\mathrm{c}}$ & $4.8( \pm 0.3)^{\mathrm{c}}$ & $-1.6( \pm 0.4)^{\mathrm{c}}$ \\
\hline
\end{tabular}

Mean values and standard deviation of BioMTA, Biodentine and MTA Angelus. Different superscript letters in the same column indicate significant differences $(\mathrm{p}<0.05)$. that showed solubility (4.1\%) in comparison to the other cements $(p<0.05)$. In contrast, MTA Angelus and BioMTA showed an increase in mass ( $-1.6 \%$ and $-4.2 \%$, respectively) showing significant differences between them $(p<0.05)$.

\section{Discussion}

The present study assessed the physicochemical properties of BioMTA, Biodentine and MTA Angelus. As the results showed differences in the physicochemical properties, the null hypothesis was rejected. BioMTA showed a short setting time, sufficient for proper handling. It also showed an alkaline $\mathrm{pH}$, radiopacity higher than the minimum recommended standard, and no solubility; in fact, it showed a gain in mass.

BioMTA shows similar composition to RetroMTA. Regarding RetroMTA, investigation in human teeth histologically showed disorganization of the pulp, dispersed mineralization, thin thickness of dentinal bridge in partial pulpotomies at eight weeks (13), and the new mineralized tissue did not exhibit regular dentin characteristics in direct pulp capping at seven months (14). However, these studies also reported good clinical/radiographic outcomes, which may be directly influenced by its physicochemical properties. The antibacterial activity of RetroMTA is comparable to ProRoot MTA against Fusobacterium nucleatum and Prevotella intermedia (15). Likewise, regarding biological properties it can induce the proliferation of stem cells of the dental papilla (16).

The physicochemical properties of a dental material have a critical role because they determine if such material is suitable for clinical use (17) radiopacity, setting time, solubility, dimensional change, and compressive strength of ProRoot MTA (PMTA). The methodology for the present study was based on ANSI/ADA No. 57 and ISO 6876 standards $(9,10)$, with some variations, such as a smaller specimen for solubility assessing (12) and the equation for radiopacity calculation (11). However, it is necessary to highlight that both standards are focused on the evaluation of root canal sealers and not for repair materials, and this could lead to a misinterpretation since the components and clinical use are different for both types of materials (18).

The setting time of an endodontic cement should be so long as to be manipulated and placed into the tooth, without gaps or displacements (19). However, extremely long setting time for clinical use would not be beneficial because the oral environment could contaminate or produce cement washout (20). In this study, BioMTA showed the
Table 3. $\mathrm{pH}$ values

\begin{tabular}{lccccc}
\hline Group & $24 \mathrm{~h}$ & 3 days & 7 days & 14 days & 21 days \\
\hline BioMTA & $10.8( \pm 0.4)^{\mathrm{a}}$ & $9.5( \pm 0.7)^{\mathrm{a}}$ & $9.4( \pm 0.9)^{\mathrm{a}}$ & $8.9( \pm 1.1)^{\mathrm{a}}$ & $9.5( \pm 0.3)^{\mathrm{a}}$ \\
Biodentine & $10.1( \pm 0.4)^{\mathrm{b}}$ & $9.5( \pm 0.6)^{\mathrm{a}}$ & $9.8( \pm 0.3)^{\mathrm{a}}$ & $9.2( \pm 1.1)^{\mathrm{a}}$ & $9.0( \pm 1.0)^{\mathrm{a}}$ \\
MTA Angelus & $7.7( \pm 0.1)^{\mathrm{c}}$ & $7.7( \pm 1.1)^{\mathrm{b}}$ & $8.0( \pm 0.2)^{\mathrm{b}}$ & $7.9( \pm 0.1)^{\mathrm{b}}$ & $8.1( \pm 0.2)^{\mathrm{b}}$ \\
Control & $6.4( \pm 0.4)^{\mathrm{d}}$ & $6.7( \pm 0.1)^{\mathrm{c}}$ & $6.0( \pm 0.2)^{\mathrm{c}}$ & $6.1( \pm 0.2)^{\mathrm{c}}$ & $6.5( \pm 0.3)^{\mathrm{c}}$ \\
\hline
\end{tabular}

Mean values and standard deviation of BioMTA, Biodentine and MTA Angelus at different time intervals. Different superscript letters in the same column indicate significant differences $(\mathrm{p}<0.05)$. 
shortest initial setting time (5.2 $\mathrm{min}$ ) compared to the other cements. These data contrast with those of the manufacturer, which indicates that the initial setting

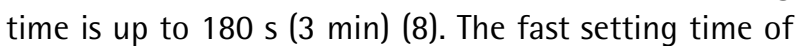
BioMTA could be attributed to a specific component of the powder; however, this information remains undisclosed by the manufacturer. The initial setting time for MTA Angelus (15.6 $\mathrm{min}$ ) and Biodentine $(27.5 \mathrm{~min})$ agree with the studies by Massi et al. (21) and Ochoa-Rodriguez et al. (22), respectively, who used a similar methodology. The long setting time for Biodentine is directly related to the powder/liquid ratio. A study showed that the alteration of the powder/liquid ratio alters the properties physicochemical including the setting time (23). Although the manufacturer recommends a mixture of 5 drops of liquid per $0.7 \mathrm{~g}$ of powder, the mixture was sandy and difficult to handle, so 6 drops were used, which allowed a better handling.

In general, all calcium silicate-based cements have alkaline activity, i.e., a high pH (17). This property is essential because it is directly related to the antimicrobial activity (24) and repair by hard tissue deposition (25) due $\vec{s}$ to a high release of calcium and hydroxyl ions (21). All cements had an alkaline $\mathrm{pH}$ at 28 days. At $24 \mathrm{~h}$, BioMTA showed the most alkaline $\mathrm{pH}$ (10.8) and then fluctuated between 8.9 and 9.5 at 21 days. This initial $\mathrm{pH}$ value for BioMTA at $24 \mathrm{~h}$ is slightly lower than that indicated by RetroMTA manufacturer 12.5 (8) and slightly higher in comparison to a previous study (5), which reported an initial $9.93 \mathrm{pH}$, fluctuating to 7.9 for RetroMTA. As this study results, they observed a reduction in $\mathrm{pH}$ over time; however, this reduction did not alter its alkalinity.

Radiopacity is a critical property because it allows the visualization of the material through the radiographs, in order to evaluate the quality of the obturation (26). The highest radiopacity was exhibited by MTA Angelus (4.8 $\mathrm{mm} \mathrm{Al}$ ), followed by BioMTA (4.2 mm Al), exceeding both cements the minimum radiopacity established by ISO 6876 (9). The presence of about 20\% bismuth oxide in the composition of the MTA (18) allowed this high value. However, the negative effects of bismuth oxide on some MTA properties led to the recommendation of other radiopacifying agents (4) such as zirconium oxide. Biodentine contains zirconium oxide in its composition (6), and showed a radiopacity of $2.2 \mathrm{~mm}$ Al. Although the content of zirconium oxide in Biodentine composition is $5 \%(6)$, this was not enough to reach the minimum of $3 \mathrm{~mm}$ Al stipulated by ISO 6876 (9). For BioMTA, the presence of $20-30 \%$ calcium-zirconium complex (8) allowed overcoming this drawback, showing to be similar to that indicated by the manufacturer. Likewise, the values of BioMTA are in line with the study by Souza et al. (5), which showed similar values for RetroMTA although they used phosphor plates instead of digitized films.

Solubility is a property that positively or negatively influences the long-term sealing of any endodontic material. After $24 \mathrm{~h}$ of immersion in water, both BioMTA and MTA Angelus showed negative values $(-4.2 \%$ and $-1.6 \%$, respectively), which indicates that both cements gained mass, which could theoretically improve the sealing. More research should be done regarding this phenomenon. The ISO 6876 and ANSI/ADA No. 57 stipulates that the solubility of the cements should not exceed $3 \%$ after 24 $\mathrm{h}(9,10)$; however, these standards do not consider the probability that cements absorb water, which may lead to the mass gain. Additionally, this study extended the test time to 7 days to simulate a more relevant clinical situation increasing the ability to discriminate the quality of materials according to their solubility (27). The MTA Angelus values agree with Torres et al. (28) who observed similar results at 7 days. Biodentine showed a solubility (4.1\%) that exceeds the 3\% recommended by ISO 6876 (9). These results are consistent with the study by Torres et al. (28), who reported that the high solubility of Biodentine could be explained due to the presence of polycarboxylate in its composition.

It is important to highlight that for a proper recommendation of BioMTA for clinical use other physicochemical and biological tests are necessary. It can be concluded that BioMTA displayed a shorter setting time, an alkaline $\mathrm{pH}$, a higher radiopacity, and a gain in mass.

\section{Resumo}

Este estudo teve como objetivo avaliar as propriedades físico-químicas de um material reparador disponivel no mercado brasileiro, BioMTA, em comparação com outros dois materiais atualmente em uso (Biodentine e MTA Angelus). 0 tempo de presa inicial foi avaliado usando a agulha de Gillmore. 0 pH foi medido com um pH-metro após 24 h, 3, 7, 14 e 21 dias. A radiopacidade foi determinada aplicando a equivalência em milimetros de alumínio ( $\mathrm{mm} \mathrm{Al}$ ) de radiografias oclusais digitalizadas. A solubilidade foi determinada após imersão em água por 7 dias. Os dados foram analisados por meio dos testes ANOVA de uma via e Tukey $(\alpha=0,05)$. 0 tempo de presa inicial do BioMTA $(5,2 \mathrm{~min})$ foi menor do que os outros materiais $(p<0,05)$. Todos os materiais apresentaram $\mathrm{pH}$ alcalino aos 21 dias. Às $24 \mathrm{~h}$, o BioMTA foi o material mais alcalino $(p<0,05)$; e aos $3,7,14$ e 21 dias não houve diferença entre BioMTA e Biodentine $(p>0,05)$, sendo ambos mais alcalinos que MTA Angelus $(p<0,05)$. A radiopacidade do BioMTA $(4,2 \mathrm{~mm} \mathrm{Al})$ foi significativamente maior em comparação ao Biodentine $(p<0,05)$ e menor que o MTA Angelus $(p<0,05)$. A solubilidade dos materiais foi de $-4,2 \%,-1,6 \%$ e 4,1\% para BioMTA, MTA Angelus e Biodentine, respectivamente, havendo diferença significativa entre eles $(p<0,05)$. Portanto, pode-se concluir que o BioMTA apresentou um menor tempo de presa, $\mathrm{pH}$ alcalino, uma alta radiopacidade e um ganho em massa.

\section{Acknowledgements}

This study was supported by São Paulo Research Foundation (FAPESP) [Grant number: 2018/24662-6] and Coordenação de Aperfeiçoamento de Pessoal de Nivel Superior - Brasil (CAPES) [Finance Code 001]. 


\section{References}

1. Parirokh $\mathrm{M}$, Torabinejad M. Mineral trioxide aggregate: a comprehensive literature review-part III: clinical applications, drawbacks, and mechanism of action. J Endod 2010;36:400-413.

2. Costa BC, Guerreiro-Tanomaru JM, Bosso-Martelo R, Rodrigues EM, Bonetti-Filho I, Tanomaru-Filho M. Ytterbium oxide as radiopacifier of calcium silicate-based cements. Physicochemical and biological properties. Braz Dent J 2018;29:452-458.

3. Coaguila-Llerena $H$, Vaisberg $A$, Velásquez-Huamán Z. In vitro cytotoxicity evaluation of three root-end filling materials in human periodontal ligament fibroblasts. Braz Dent J 2016;27:187-191.

4. Marciano MA, Costa RM, Camilleri J, Mondelli RFL, Guimarães BM, Duarte MAH. Assessment of color stability of white mineral trioxide aggregate Angelus and bismuth oxide in contact with tooth structure. J Endod 2014;40:1235-1240.

5. Souza LC de, Yadlapati M, Dorn SO, Silva R, Letra A. Analysis of radiopacity, $\mathrm{pH}$ and cytotoxicity of a new bioceramic material. J Appl Oral Sci 2015;23:383-389.

6. Li X, Yoshihara K, De Munck J, Cokic S, Pongprueksa P, Putzeys E, et al. Modified tricalcium silicate cement formulations with added zirconium oxide. Clin Oral Investig 2017;21:895-905.

7. Camilleri J, Sorrentino F, Damidot D. Investigation of the hydration and bioactivity of radiopacified tricalcium silicate cement, Biodentine and MTA Angelus. Dent Mater 2013;29:580-593.

8. BioMTA. RetroMTA. Available at: http://www.biomta.com/shop/eng/ product_5.php? \&. Accessed September 20, 2020.

9. International Organization for Standardization. ISO 6876:2012-Dentistry: root canal sealing materials. Geneva:ISO;2012.

10. American National Standards Institute /American Dental Association. Laboratory testing methods: endodontic filling and sealing materials. Specification $n^{\circ}$ 57. ADA Professional Product Review 3,2008:1-10.

11. Húngaro Duarte MA, de Oliveira El Kadre GD, Vivan RR, Guerreiro Tanomaru JM, Tanomaru Filho M, de Moraes IG. Radiopacity of portland cement associated with different radiopacifying agents. J Endod 2009;35:737-740.

12. Carvalho-Junior JR, Correr-Sobrinho $L$, Correr AB, Sinhoreti MAC, Consani $S$, Sousa-Neto MD. Solubility and dimensional change after setting of root canal sealers: a proposal for smaller dimensions of test samples. J Endod 2007;33:1110-1116.

13. Bakhtiar H, Aminishakib P, Ellini MR, Mosavi F, Abedi F, Esmailian S, et al. Dental pulp response to RetroMTA after partial pulpotomy in permanent human teeth. J Endod 2018;44:1692-1696.

14. Dammaschke T, Nowicka A, Lipski M, Ricucci D. Dammaschke T, Nowicka A, Lipski M, Ricucci D. Histological evaluation of hard tissue formation after direct pulp capping with a fast-setting mineral trioxide aggregate (RetroMTA) in humans. Clin Oral Investig 2019;23:4289-4299.

15. Khedmat $S$, Aminipor $M$, Pourhajibagher $M$, Kharazifar MJ, Bahador $A$. Comparison of antibacterial activities of ProRoot MTA, OrthoMTA, and RetroMTA against three anaerobic endodontic bacteria. J Dent (Tehran) 2018;15:294-299.
16. Wongwatanasanti N, Jantarat J, Sritanaudomchai $H$, Hargreaves KM. Effect of bioceramic materials on proliferation and odontoblast differentiation of human stem cells from the apical papilla. J Endod 2018;44:1270-1275

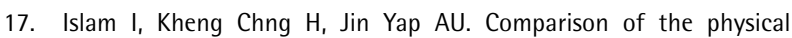
and mechanical properties of MTA and portland cement. J Endod 2006;32:193-197.

18. Camilleri J. Evaluation of the effect of intrinsic material properties and ambient conditions on the dimensional stability of white mineral trioxide aggregate and portland cement. J Endod 2011;37:239-245.

19. Collares FM, Klein M, Santos PD, Portella FF, Castelo V, Leitune B, et al. Influence of radiopaque fillers on physicochemical properties of a model epoxy resin-based root canal sealer. J Appl Oral Sci 2013;3:533539.

20. Ber BS, Hatton JF, Stewart GP. Chemical modification of ProRoot MTA to improve handling characteristics and decrease setting time. J Endod 2007;33:1231-1234

21. Massi $\mathrm{S}$, Tanomaru-Filho $M$, Silva GF, Duarte MAH, Grizzo LT, Rabelo Buzalaf $\mathrm{MA}$, et al. $\mathrm{PH}$, calcium ion release, and setting time of an experimental mineral trioxide aggregate-based root canal sealer. J Endod 2011;37:844-846.

22. Ochoa-Rodríguez VM, Tanomaru-Filho M, Rodrigues EM, GuerreiroTanomaru JM, Spin-Neto R, Faria G. Addition of zirconium oxide to Biodentine increases radiopacity and does not alter its physicochemical and biological properties. J Appl Oral Sci 2019;27.

23. Cavenago $B C$, Pereira TC, Duarte $M A H$, Ordinola-Zapata $R$, Marciano $\mathrm{MA}$, Bramante $\mathrm{CM}$, et al. Influence of powder-to-water ratio on radiopacity, setting time, $\mathrm{pH}$, calcium ion release and a micro-CT volumetric solubility of white mineral trioxide aggregate. Int Endod J 2014;47:120-126.

24. McHugh $C$, Zhang $P$, Michalek $S$, Eleazer $P$. pH required to kill Enterococcus faecalis in vitro. J Endod 2004;30:218-219.

25. Holland R, De Souza V, Nery MJ, Estrada Bernabé PF, Otoboni Filho JA, Dezan $E_{1}$ et al. Calcium salts deposition in rat connective tissue after the implantation of calcium hydroxide-containing sealers. J Endod 2002;28:173-176.

26. Candeiro GTDM, Correia FC, Duarte MAH, Ribeiro-Siqueira DC, Gavini $\mathrm{G}$. Evaluation of radiopacity, $\mathrm{pH}$, release of calcium ions, and flow of a bioceramic root canal sealer. J Endod 2012;38:842-845.

27. Elyassi $Y$, Moinzadeh AT, Kleverlaan CJ. Characterization of leachates from 6 root canal sealers. J Endod 2019;45:623-627.

28. Torres FFE, Bosso-Martelo R, Espir CG, Cirelli JA, Guerreiro-Tanomaru JM, Tanomaru-Filho M. Evaluation of physicochemical properties of root-end filling materials using conventional and Micro-CT tests. J Appl Oral Sci 2017;25:374-380.
Received December 7, 2019

Accepted May 4, 2020 